\title{
THE TALENT MANAGEMENT AND EMPLOYEE JOB SATISFACTION
}

\author{
Dr. C K GOMATHY, Ms. TEJASWI.D , MS. ANVITHA.B, MR. LOKESH. A \\ Sri Chandrasekharendra Saraswathi Viswa Mahavidyalaya, Kanchipuram
}

\section{ABSTRACT}

Talent management is the core functional unit of an organization, and in order to enhance the productive performance of employees ,talent management uses human resources planning to achieve this goal. To make them a part to talent management and strategic workspace planning, efforts have been made to retain, develop, attract, and reward employees. Keeping in the mind necessity of talent management, this paper analyzes probable scenarios of talent managements practices in public sector banks and how these practices ,in turn, improve bank employees performance. Talent management can lead to higher level performance and satisfaction of employees instead of being a process of hiring, reinforcing and evaluating the aptitude. Furthermore, it examined how talent management practices could influence the employees satisfaction in Indian public sector banks . This research paper puts forward a set of valid hypotheses that talent management practices affect employee performance and satisfaction. The study will tender to the talent management literature by pondering how talent management practices affect the organizational outcomes, such as employee satisfaction and performance. This paper seeks to confirm these hypotheses on a survey based on data collected from the employees of the public sector banks in Indian states.

Keywords: talent management; employee satisfaction; employee performance.

\section{I . INTRODUCTION}

Talent Management is considered the backbone of HRM, as it helps investment in those who many offer future potency to meet the decisive objectives of the organization. Talent management is an internal set of process, programs and cultural norms in an organization designed and enforced to attract, develop, deploy, and hold talents to achieve strategic aims and meet future business demands. It is the number one concern of all top organizations in the world right now. To be able to take advantage of the changing and growing markets, the organization must have right people in place. Talent management helps in covering long-standing practices which aim at getting the right person in the right place. Having skilled employees implies that organizations must know how to identify, manage, develop keep and get the best out of their right people.

Talent management is concerned with sourcing talent, integrating and aligning talent, developing talent, engaging and rewarding talent, and assuring that there is an adequate talent pipeline to support the business as it moves towards its strategic goals. Talent management strategies help in getting employees engaged with both heart and minds to their work tasks with complete enthusiasm. It focuses on developing and retaining skilled talent, and improves the chance of better recruits at all levels of the organizations. However, it is not enough to enhance the performance of an 
organization. The real success comes when the heart and minds of individuals in an organization are engaged. Being engaged is something which is more related to employee heart than their minds because feelings and emotions drive an individual behavior. So hoe employees and organizations make their jobs makes a positive impact on their performance.

\section{II . SIGNIFICANCE OF THE STUDY}

The study is specifically important in view of the gains associated with the application. The study elucidate on the nature and role of talent management in intensify employee satisfaction

\section{BACKGROUND OF THE STUDY}

Talent management includes the proficiency of recruiting, retaining, and producing the best talented employees existing in an available job market. Talented employees enchant benefits to the organization in providing customer satisfaction, high revenue yield, quality service, lower cost, high productive, market capitalization and cycle time. Talent management dispense the organization with employees with its relevant knowledge, quality skills, high potentials and cognitive abilities. Job satisfactions constitute a main factor in employee retention as either a talent employee is satisfied with the job or quits the job. Solely, it is main for career success. Job satisfaction leads to the increase of employee's individual's performance and personal satisfaction.

Talent management, places employees on the right jobs with intelligible career path thereby leading to employees' job satisfaction despite of the benefit of talent management the greater challenge lies on the preservation of this talented workers in view of the competitive business environment offering new opportunities to employees

\section{PROBLEM STATEMENT}

Talent control includes the competence of recruiting, retaining, and generating the great gifted personnel current in an to be had task marketplace. Talented personnel appeal to advantages to the employer in offering consumer satisfaction, excellent service, excessive sales yield, decrease cost, excessive productivity, cycle time, and marketplace capitalization. Inspite of the advantage of expertise control the extra undertaking lies at the protection of this gifted employees in view of the competitive enterprise surroundings presenting new possibilities to personnel. It is likewise pertinent to notice that best few organization makes a speciality of skills control and their management shape withinside the technique of human useful resource and organizational control. They make investments on new technologies, working structures and software program making plans however lack the competence of Talent control even if the closing achievement of the company lies with gifted personnel. While present day organizations, is aware of their upgrades relies upon at the group of workers funding and looking to manual skills group of workers to the last success .

\section{JOB SATISFACTION FACTORS}

\section{Compensation \& Working conditions:}

One of the major factors of job satisfactions are the compensation and working conditions. An employee with a superior salary, bonuses, incentives, healthcare options etc. is happier with their job as comparing to someone who doesn't have the same. A quality and healthy workplace environment also attach value to an employee. 


\section{Work life balance:}

Every individual employee wants to have a ethical workplace which allows them time to spend with their time family \& friends. Job satisfaction for employees is often due a good work life balance policy, which make sures that an employee spends plenty time with their family along with doing their work. This improves the employee's quality of work life.

\section{Respect \& Recognition:}

Any individual employee appreciates and feels motivated if they are respected at their workplace. Besides, if they are awarded for their hard work, it furthermore motivates employees. Therefore, recognition is one of the job satisfaction factors.

\section{Job security:}

If an employee is guaranteed that the company would employ them even if the market is turbulent, it gives them massive confidence. Job security is one of the major reasons for job satisfaction for employees.

\section{Challenges:}

Monotonous work activities can lead to dissatisfied employees. Hence, things like job rotation, job enrichment etc can help in job satisfaction of employees as well.

\section{Career Growth:}

Employees always keep their career growth part as a high priority in their life. Hence, if a company helps groom employees and gives them newer job roles, it enhances the job satisfaction as they know they would get a boost in their career.

There are several theories given which help in evaluating \& measuring job satisfaction of employees at workplace. Some of them are:
- Hierarchy of Needs by Maslow

- Hygiene Theory by Herzberg

These help in understanding the parameters or factors which influence job satisfaction of employees at workplace.

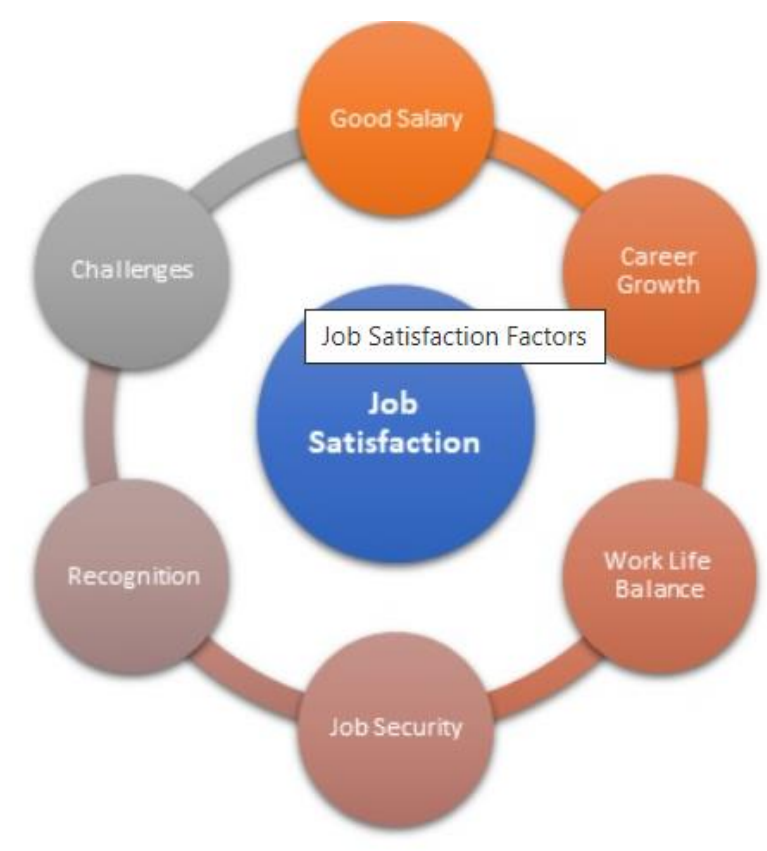

Fig 1: Job satisfaction factors

\section{CONCLUSION}

By observing all these methods and implementation in job satisfaction makes an employee feel happy and do his work more effectively with good work and leads to success even makes a company grow faster and develop With employees job satisfaction. Employee job satisfaction leads to success and growth of company in greater manner and helps in improvement of a company.If an employee is satisfied he will show all his happiness and more talent towards his work and leads to success 


\section{VII . REFERENCES}

1.Dr.C K Gomathy, Article: A Study on the recent Advancements in Online Surveying, International Journal of Emerging technologies and Innovative Research ( JETIR ) Volume 5 | Issue 11 | ISSN : 2349-5162, P.No:327-331, Nov-2018

2.Dr.C.K.Gomathy,C K Hemalatha, Article: A Study On Employee Safety And Health

Management International Research Journal Of Engineering And Technology (Irjet)- Volume: 08 Issue: 04 | Apr 2021

3. Dr.C K Gomathy, Article: A Study on the Effect of Digital Literacy and information Management, IAETSD Journal For Advanced Research In Applied Sciences, Volume 7 Issue 3, P.No-51-57, ISSN NO: 2279-543X,Mar/2018

4. Dr.C K Gomathy, Article: An Effective Innovation Technology In Enhancing Teaching And Learning Of Knowledge Using Ict Methods, International Journal Of Contemporary Research In Computer Science And Technology (Ijcrcst) E-Issn: 2395-5325 Volume3, Issue 4,P.No-10-13, April '2017

5.Dr.C K Gomathy, Article: Supply chain-Impact of importance and Technology in Software Release Management, International Journal of Scientific Research in Computer Science Engineering and Information Technology ( IJSRCSEIT ) Volume 3 | Issue 6 | ISSN : 2456-3307, P.No:1-4, July-2018

\section{AUTHOR'S PROFILE:-}

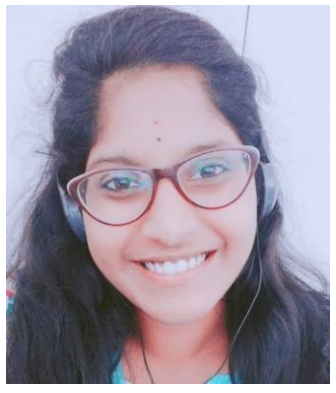

\section{Ms. TEJASWI.D}

Student ,B.E in Computer

Science and Engineering, Sri

Chandrasekharendra

Saraswathi Viswa Maha

Vidhyalaya, Enathur,

Kanchipuram, India.

Her area of interest in Human Resources

Development

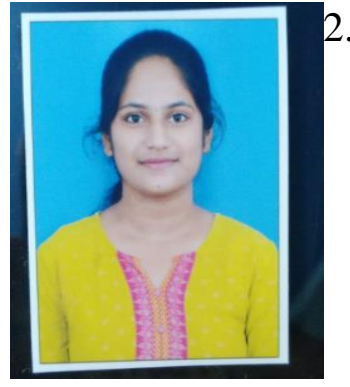

2. MS. ANVITHA.B Student, B.E in Computer Science and Engineering, Sri ChandraSekhrendra Saraswathi Viswa MahaVidyalaya Enathur ,Kanchipuram, India.

Her area of interest in Human Resources Development.

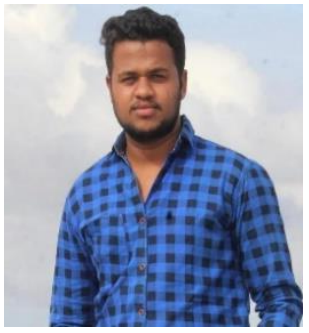

3. MR. LOKESH . A

,Student, B.E in Computer Science and Engineering, Sri

Chandrasekharendra Saraswathi Viswa MahaVidyalaya,Enathur, Kanchipuram, India. His area of interest in Human Resources

Development.

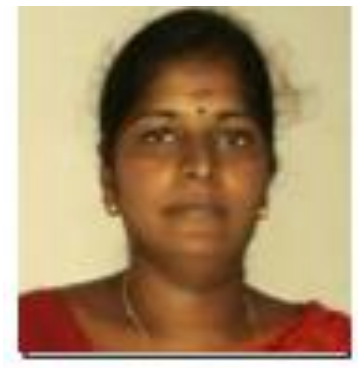

4. Dr.C.K.Gomathy is Assistant Professor in Computer Science and Engineering at Sri Chandrasekharendra Saraswathi Viswa

MahaVidyalaya,Enathur,Kanchipuram,India.Her area of interest in Software Engineering,Web Services, Human Resource Management, Knowledge Management and IOT. 